\title{
SMARCA2 Gene
}

National Cancer Institute

\section{Source}

National Cancer Institute. SMARCA2 Gene. NCI Thesaurus. Code C19879.

This gene plays a role in chromatin remodeling and transcriptional activation of genes normally repressed by chromatin. 